\title{
Structural heterogeneity and old-growthness: A first regional-scale assessment of Sardinian forests
}

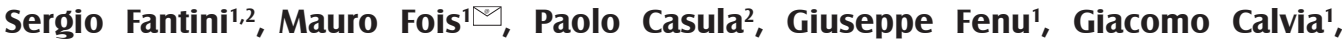 \\ Gianluigi Bacchetta'
}

Fantini S., Fois M., Casula P., Fenu G., Calvia G., Bacchetta G., 2020. Structural heterogeneity and old-growthness: A first regional-scale assessment of Sardinian forests. Ann. For. Res. 63(2): 103-120.

Abstract Mediterranean forests have been altered by several human activities. Consequently, relatively intact forests that have been unmodified by humans for a relatively long time (i.e., old-growth forests) are often reduced to isolated and fragmented stands. However, despite their high conservation value, little is known about their features and even presence several Mediterranean areas. First steps of their investigation are based on the identification of old-growth features such as amount of large-size and old trees, tree species composition, canopy heterogeneity, occurrence and amount of deadwood. The Structural Heterogeneity Index (SHI) is commonly used to summarise features of old-growthness in one single value. Here, the SHI was derived for 68 plots included in 45 forest stands within the $4,297 \mathrm{~km}^{2}$ of territory that is covered by forests in Sardinia. SHI values were affected by variables that are likely to be related to forest age and structural complexity, such as presence of cerambycids, canopy cover, forest layers, location and three old-growthness classes. Results confirm a high structural variability among forests with old-growth features, determined by the presence, or lack, of given living and deadwood features. Our findings identified, for the first time, most of the forest stands that need special protection in Sardinia for the presence of old-growth features. In this sense, the SHI was confirmed useful for improving their management and conservation, although more specific and deeper studies are necessary for better understanding their species composition and dynamics.

Keywords: old-growth forests; forest ecosystems conservation; Mediterranean Basin; Structural Heterogeneity Index

Addresses: ${ }^{1}$ Centro Conservazione Biodiversità (CCB), Dipartimento di Scienze della Vita e dell'Ambiente, Università degli studi di Cagliari, Cagliari, Italy| ${ }^{2}$ UServizio tecnico, Agenzia Forestas, Cagliari, Italy.

$\square$ Corresponding Author: Mauro Fois (mfois@unica.it).

Manuscript received July 23, 2020; revised December 24, 2020, accepted December 28, 2020 


\section{Introduction}

Forest ecosystems have been subject to human exploitation for millennia, since the establishment of the first agricultural societies in the mid-Holocene, mainly for fuel wood production, food, cropland, pasture, and construction materials (Parviainen 2005, Kaplan et al. 2009). The impact is more pronounced where the stable presence of humans is historically documented, like in Europe and especially in the Mediterranean Basin (Grove \& Rackham 2001). Despite being one of the most threatened by current changes (Gauquelin et al. 2018), plant diversity in the Mediterranean Basin is still high, primarily as a result of habitat diversity (Fois et al. 2017). Among them, thermophilous deciduous, broadleaved evergreen and coniferous forests and woodlands represent a wide range of habitats of conservation concern in the Mediterranean (Gauquelin et al. 2018). In this context, human disturbance has, among others, caused simplification of forest structure, changes in plant composition, abundance and distribution (Blasi et al. 2010, Abadie et al. 2018). Moreover, forest conversions into managed systems have been proven to decrease the capacity of storing carbon below ground due to simplification of foliage and root litter inputs (Błonska et al. 2020).

A long-lasting history of land use has reduced forests without visible human interventions to cover in Europe about $0.25 \%$ of land (Sabatini et al. 2018). This is particular evident in the southern shore of the Mediterranean Basin, where forest degradation, mainly as a result of intensive wood collection and livestock grazing, is still intense and leads to their fragmentation or disappearance (Gauquelin et al. 2018) or in countries, like Italy, where forest structure since Roman times has been greatly influenced by man (Chiavetta et al. 2012). Exotic trees species such as Pinus spp., Eucalyptus spp. and Acacia spp. have been largely used to restore degraded Mediterranean ecosystems, which are now modifying the natural structure and composition of plant cover and the vegetation successions (Gauquelin et al. 2018). This situation is even exacerbated in the southern Mediterranean by global warming, which is expected to result in increased frequency, intensity and duration of drought, heat stress and wildfires (Cardil et al. 2014, Gauquelin et al. 2018, Arar et al. 2020).

Naturally regenerated forests of native species, where there are no clearly visible signs of human activities and ecological processes are not significantly disturbed, are generally called primary forests (FAO 2015). These often isolated primary forest stands recover compositional, structural and functional features and can be also defined old-growth forests or long untouched forests (Buchwald 2005, Chirici \& Nocentini 2013). As a forest ages, peculiar structural features develop, for instance through the accumulation of high quantities of large trees and deadwood, which determines an increase in general complexity (=heterogeneity) of the forest structure (Burrasacano et al. 2018). Besides being extremely complex in structure (Motta et al. 2015), recent researches has highlighted that old-growth forests, especially in the Mediterranean, are characterised by hosting an especially high number of species of conservation concern for several taxonomic groups such as invertebrates, bryophytes, lichens, and vascular plants (Janssen et al. 2009, Brunialti et al. 2010, Vicol 2016). However, the response of biodiversity to the cessation of management remains in many aspects unclear, due to the interdisciplinary and time-consuming efforts required, joined to site-specific socio-ecological features that differently drive forest dynamics in different contexts (Paillet et al. 2010, Burrascano et al. 2018).

Due to the low knowledge level about such old-growth forests and woodlands in several Mediterranean landscapes, first steps towards their understanding focus on indices or proxies of "old-growthness". Structural components of 
forests are often used for the relative simplicity in measuring, calculating and interpreting their variability (McElhinny et al. 2006, Sabatini et al. 2015). Among forest features that have been used to rank the old-growthness of forests and stands, the most common are: occurrence and amount of large-size and old trees, tree species composition, canopy heterogeneity, occurrence and amount of deadwood, lack of human disturbance, and gap dynamics (Burrascano 2010, Ziaco et al. 2011). Because no one single proxy indicator is able to be a measure of old-growthness alone, various indices have been elaborated in order to summarise various forest characteristics in one single value (Storch et al. 2018). Ideally, this would allow a quantification and comparison of old-growthness of different stands and provide an indication of their potential contribution to biodiversity (Parkes et al. 2003). Measures of structural complexity were elaborated in several contexts (e.g., McElhinny et al. 2006, Sabatini et al. 2015); these were based on a core of attributes collected from standardised plots arranged within each stand. Each attribute is quantified proportionally to the observed level and combined with others through an additive index. The rationale of this approach is that forest ecosystems containing stands with a variety of structural components are considered likely to have a variety of resources and species that utilise these resources. In fact, there is often a positive correlation between elements of biodiversity and measures of the variety and/or complexity of structural components within forest ecosystems (McElhinny et al. 2006, Parisi et al. 2016).

In the Mediterranean Basin, Amici et al. (2013) showed that light-demanding species richness decreased with increasing successional age of forest. Plant species in old-growth forests are often specialists, with short distance dispersal mechanisms and no persistent soil seed bank, which makes them more vulnerable to forest habitat loss (Burrascano et al. 2009, Campetella et al. 2016, Abadie et al. 2018).
Saprobic fungi diversity is often particularly high in temperate and boreal old-growth forests (Ohlson et al. 1997), even though this was not confirmed in drier conditions, like in Corsica, where ectomycorrhizal fungi were dominant (Richard et al. 2004). Also, some lichens, such as Lobaria pulmonaria (L.) Hoffm., Antitrichia curtipendula Bridel-Brederi, and Homalothecium sericeum (Hedw.) Schimp. (Brunialti et al. 2010), and invertebrates, like Cerambyx cerdo L. (Casula 2017), are found as indicators of old-growth features in Mediterranean forests. Despite such a kind of promising results, compared to temperate contexts, old-growth forests have been much less explored in the Mediterranean (Abadie et al. 2018). Patched and uncomplete information is present at this scale, and exhaustive literature on old-growth dynamics and features is available for only few Mediterranean territories, such as the Cilento, central Italy or eastern Pyrenees (e.g., Marchetti et al. 2010, Lombardi et al. 2015, Fortuny et al. 2020).

Such first-step research work, towards a knowledge improvement about old-growth forests, is therefore needed in Sardinia, the second largest island of the Mediterranean Basin. Although a recent increase in forest cover occurred mainly due to the spontaneous colonisation of marginal agricultural areas, following the abandonment of crops (INFC, 2015), the extension of old-growth forests in Sardinia was estimated to be considerably reduced during the nineteenth century, mainly due to deforestation, subsequent livestock, coupled with fire to maintain pastures (Pungetti 1995, Caterini 2013). Nonetheless, several small and scattered stands remained untouched in remote mountainous areas of the Island. Despite their high conservation value, there is not much knowledge about the distribution, composition, structure and function of the residual fragmented stands of old-growth forests in Sardinia (hereafter forest stands). In this study, our goals were thus to: i) identify forests stands with old-growth 
features in Sardinia and evaluate their degree of structural heterogeneity; ii) investigate how the structural heterogeneity index varies across biological, environmental or human-related factors; iii) identify strengths and limitations of the structural heterogeneity index as an informative tool for the conservation and management of Mediterranean old-growth forest.

\section{Materials and methods}

\section{Study area}

The reference area of this study is the island of Sardinia (Fig. 1), the second Mediterranean island after Sicily by extension, with a surface area of about $24,090 \mathrm{~km}^{2}$. Sardinia is located in the central-western part of the Mediterranean Sea and, together with Corsica and the Tuscan Archipelago, it constitutes an independent biogeographical province (Fenu et al. 2014). The island is underpopulated compared to other Italian and European regions: it has a population density of 68 inhabitants per $\mathrm{km}^{2}$, compared to the average of 200 people per $\mathrm{km}^{2}$ for Italy (ISTAT 2019). Around $40 \%$ of Sardinians live in urbanised areas in the North of the island (Sassari) and in the South (Cagliari).

The mountainous inland areas of Sardinia are still relatively isolated and sparsely populated where the island preserves many natural environments with difficult access, partly wild and relatively well preserved (Fois et al. 2019). For the high concentration of endemic species (especially plants and invertebrates), it has been identified as a biodiversity hotspot of global and regional importance (Biondi et al. 2013, Fois et al. 2018).

Forests in Sardinia have been estimated to cover a surface of 4,297 $\mathrm{km}^{2}$ (Puddu et al. 2012), which mainly consists of holm oak (Quercus ilex L.) and cork oak (Quercus suber L.) evergreen forests and forests of deciduous oak woods (Quercus congesta C. Presl and
Q. ichnusae Mossa, Bacch. \& Brullo), with a wide ecological range and a widespread distribution throughout the island, from coastal areas up to $1400 \mathrm{~m}$ above sea level. These formations constitute a wide range of potential climax forests, some of them endemic to the island, such as the Glechomo sardoaeQuercetum congestae or the Prasio majorisQuercetum ilicis quercetosum virgilianae (Bacchetta et al. 2004a,b, 2009).

Furthermore, particular soil-climatic conditions support the instauration of several formation types, which make the island very diverse in this aspect. One of the most interesting examples are relic yew (Taxus baccata L.) forests, which can be found mainly in the central-northern sectors of Sardinia, often limited to gorges or high slopes, in soils often rich in skeleton (Farris et al. 2012). Other potential natural forests are summarised in Bacchetta et al. (2009) and are represented, in peculiar soil-climatic conditions, by

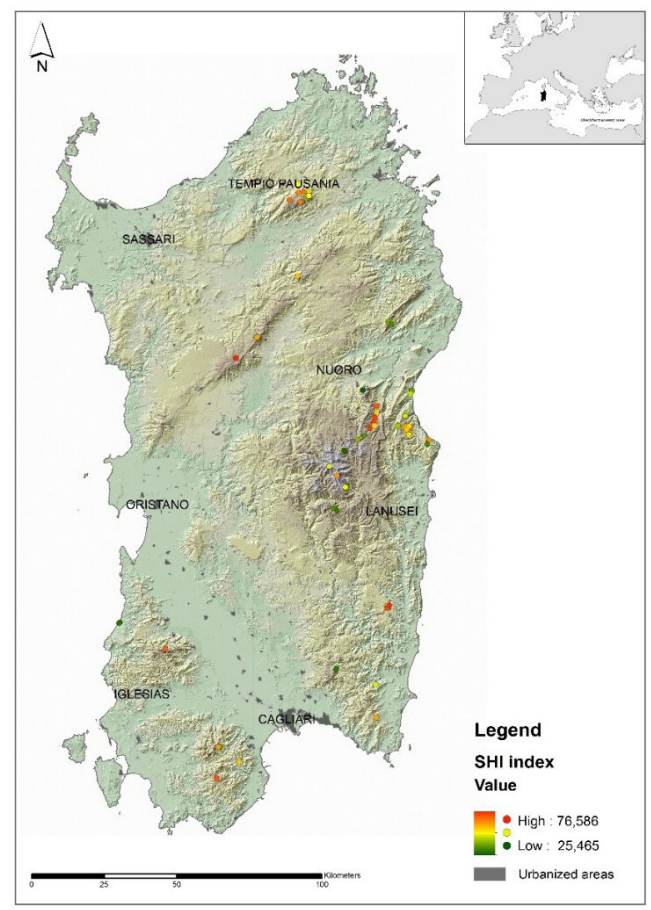

Figure 1 Plots distribution map and SHI ranges 
formations of hop hornbeam (e.g., Cyclamino repandi-Ostryetum carpinifoliae), junipers (e.g., Chamaeropo humilis-Juniperetum turbinatae), phillyreas (e.g., Prasio majorisQuercetum phillyretosum latifoliae) and olive trees (e.g., Asparago albi-Oleetum sylvestris). Riparian forests are mainly constituted by black alders (Alnus glutinosa (L.) Gaertn.), willows and poplars (Salix spp. and Populus spp.), tamarisks (Tamarix spp.) and oleanders (Nerium oleander L.). Planitial woods of silver poplars (Populus alba L.), raywoods (Fraxinus oxycarpa Willd.) and field elms (Ulmus minor Mill.) are also present in few and small alluvial planes.

\section{Selection of study forest stands}

The investigated forest stands were identified through a questionnaire sent to local experts from research institutes universities and public forestry agencies. Forest stands were reported by indicating the location and describing main forest characteristics, including the presence of large old trees, dead wood, and human disturbance. The full questionnaire is available on supplementary material (Table S1, Supp. Info.). Each stand was considered to be inventoried or not, after a first screening in the field of the following features: presence of dead wood, large trees, and negligible signs of recent human presence. In other words, the forest stands reported in the questionnaires that showed clear signs of management, like pure coppices, were not inventoried.

\section{Variables selection and collection}

The selected forest stands were sampled following methods described in the National Inventory of Forests and forest Carbon reserve INFC2015 (Gasparini et al. 2016). Within each surveyed stand, circular plots of $13 \mathrm{~m}$ radius (approx. $530 \mathrm{~m}^{2}$ ) were positioned. Such plot surface was considered as enough for providing a reliable inventory in old-growth forest conditions (Lombardi et al. 2015).

The sampling effort (i.e., number of plots per stand) was determined by the need to survey the most representative as possible number of stands reported by the questionnaires on a regional scale. Random plots within each oldgrowth stand were positioned as following: hiking tracks were walked and, once inside the old-growth stand, a random direction was selected and a constant distance of about 100 $\mathrm{m}$ walked to reach the centre of the plot. In very small stands, this distance was reduced to $50 \mathrm{~m}$ to avoid old-growth forest edges. In any case, plots were positioned at least $100 \mathrm{~m}$ from edges. At least one plot per each reported forest stand was surveyed and, where forest stand was suitable and topography allowed it (i.e., time to reach localities, accessibility, forest stand extension), up to 10 plots per stand and four plots per day were investigated.

In each plot, the following parameters were considered: heights of all live trees, with a minimum diameter of $9.5 \mathrm{~cm}$ at breast height $(\mathrm{DBH})$, were measured with a Blume-Leiss ipsometer for an as much as possible number of individuals and at least for $10 \%$ of the total number. These were used as standard comparison for measuring the remaining trees. Length and diameters (minimum, maximum and average) of the three different kinds of deadwood (deadwood debris, stumps and standing dead trees) were recorded, as well as their decay level according to the 1-5 scale proposed by Hunter (1990). Deadwood debris on the ground was measured with a minimum diameter $\geq 9.5 \mathrm{~cm}$. The volume was calculated according to Huber's formula (Fridman \& Walheim 2000):

$$
\mathrm{V}=\mathrm{S} 0.5 \times \mathrm{h}
$$

where S0.5 is the median sectional area, $\mathrm{h}=$ length. We considered as stumps the truncated stems at a height of less than $1.30 \mathrm{~m}$ from the ground, whose diameter on the cutting plane is equal or greater than $9.5 \mathrm{~cm}$. The volume of 
stumps was computed by equation:

$$
\mathrm{V}=\pi \times \mathrm{h} / 3 \times[(\mathrm{D} / 2)+(\mathrm{d} / 2)+(\mathrm{D} / 2) \times(\mathrm{d} / 2)]
$$

where $\mathrm{V}$ is the volume; $\mathrm{h}$ is the height; $\mathrm{D}$ is the maximum diameter, and $\mathrm{d}$ is the minimum diameter (Lombardi et al. 2013).

Since no volume tables are available, the estimate of the volume of live trees was performed using the model tree method, applying the general equation of standing trees for each plant:

$$
\mathrm{V}=\pi / 4 \times \mathrm{H} \times \mathrm{F}=\mathrm{G} \times \mathrm{H} \times \mathrm{F}
$$

in which $\mathrm{D}$ is the diameter with bark measured at $1.30 \mathrm{~m}$ from the ground, $\mathrm{G}$ is the basal area and corresponds to the surface of the cross section at $1.30 \mathrm{~m}, \mathrm{H}$ is the estimated height of the plant and $\mathrm{F}$ is the reduction coefficient. The reduction coefficient $(0<\mathrm{X}<1)$ can be calculated exactly only on felled plants which are the model trees. As this is not foreseen in our study, it was estimated based on a representative sampling of the average shape of one or more plants of the stand (Bernetti \& La Marca 1983).

\begin{tabular}{|c|c|c|c|}
\hline $\mathrm{n}$ & Code & Variable description & Data typology \\
\hline 1 & $\mathrm{BA}$ & Basal area & $\mathrm{D}$ \\
\hline 2 & BASnagST & Basal area of standing dead trees and stumps & $\mathrm{D}$ \\
\hline 3 & $\mathrm{CC}$ & Canopy cover \% & $\mathrm{E}$ \\
\hline 4 & CWD & Coarse woody debris volume & $\mathrm{D}$ \\
\hline 5 & DensNLiv & Living trees density & $\mathrm{D}$ \\
\hline 6 & DensStuDW & Standing dead trees including stumps density & $\mathrm{D}$ \\
\hline 7 & Dw/Liv & Deadwood/living wood volume ratio & $\mathrm{D}$ \\
\hline 8 & Dwtot & Total deadwood volume & $\mathrm{D}$ \\
\hline 9 & GSDBH & DBH diversity (calculated using the Gini-Simpson index) & $\mathrm{D}$ \\
\hline 10 & QMDDBH & Quadratic mean DBH & $\mathrm{D}$ \\
\hline 11 & $\mathrm{HM}$ & Maximum height & $\mathrm{E} / \mathrm{D}$ \\
\hline 12 & $\mathrm{Hm}$ & Average height & $\mathrm{D}$ \\
\hline 13 & Hsd & Height standard deviation & $\mathrm{E}$ \\
\hline 14 & Lam & Lichens and mosses layer \% & $\mathrm{E}$ \\
\hline 15 & LenghtCWD & Total length of coarse woody debris & M \\
\hline 16 & Liv & Living trees volume & $\mathrm{E}$ \\
\hline 17 & NDBH & Number of diameters classes & M \\
\hline 18 & NDC & Number of decay classes occurring in the plot & M \\
\hline 19 & NHt & Number of hollow trees & M \\
\hline 20 & NstuStDW & Number of standing dead trees including stumps & M \\
\hline 21 & RDBH & Range of diameters distribution & $\mathrm{D}$ \\
\hline 22 & STDw & Standing dead trees volume & $\mathrm{D}$ \\
\hline 23 & STUMPS & Stumps volume & $\mathrm{D}$ \\
\hline 24 & STUStDw & Standing dead trees including stumps volume & $\mathrm{D}$ \\
\hline 25 & $\mathrm{~T}>40$ & Number of living trees with $\mathrm{dbh}>40 \mathrm{~cm}$ & M \\
\hline 26 & TreeRich & Tree species richness & M \\
\hline
\end{tabular}

Table 1 Variables identified measured (M) and estimated (E) in the field or derived (D) 
Data collected in the field and derived in the laboratory (26 structural variables) were used for the elaboration of an index of structural heterogeneity (Table 1). These variables comprise those commonly found in national forest inventories and reported in the literature of old-growth forests and forest structural complexity (McElhinny et al. 2005, Sabatini et al. 2015).

Other indicators of old-growthness, such as number of hollow trees (Lindenmayer et al. 2000, McElhinny et al. 2006, Rozas 2006), the type of layering of the canopy (single, double, multi) (Franklin \& Van Pelt 2004), the percentage of canopy (Jennings et al. 1999, Franklin \& Van Pelt 2004) and lichen-muscinal covers (Lesica et al. 1991, Ódor \& Standovár 2001) were also recorded. Furthermore, the presence of the large longhorn beetles (Cerambyx cerdo, Aegosoma scabricorne (Scopoli) and Prinobius myardi Mulsant), generally associated with mature trees and aging forests (Parisi et al. 2016, Casula 2017), was also recorded. This was established by searching for exit holes of longhorn beetle adults (larger diameter of about $20 \mathrm{~mm}$ ) in the lower part of the trunks. The presence of livestock grazing was evaluated by the searching for faecal material, presence of grazing signs and by interviewing local people. Finally, forest types were defined based on the relative dominance (basal area) of the recorded tree species. Mixed forest stands were those without a species representing more than $75 \%$ of the total basal area. Such mixed stands were defined by species representing at least $25 \%$ of the total basal area (Gauthier et al. 1996).

\section{Elaborating and evaluating the Structural Heterogeneity Index (SHI)}

A simplified structural index was elaborated according the methodology developed by McElhinny et al. (2005) and Sabatini et al. (2015). The number of variables was reduced from 26 to eight, identifying a single attribute that best represented each of the eight categories of complexity recognised for the old-growth forests in Italy (Sabatini et al. 2015): (1) vertical heterogeneity (VH); (2) compositional diversity (CH); (3) uneven agedness (UA); (4) density of large living trees (LLT); (5) growing stock (GS); (6) total deadwood volume (DWTOT); (7) deadwood decay classes (DW-DC); (8) standing deadwood, dead trees and stumps (DW-ST).

Each of the eight variables was selected according to the following criteria: (1) to have a kurtosis $<2$, in order to avoid attributes with a non-normal distribution and a low discrimination ability: for those attributes that showed a high Kurtosis value $(>2)$, their distribution was corrected through the logarithmic or the square root transformation; (2) to be not correlated with other attributes: strengths of correlation were estimated by Spearman correlation coefficients. Accordingly, the number of attributes was reduced by choosing only one among those having a correlation coefficient $<0.50$; (3) to have the highest as possible contribution of variations retained by two principal components $\mathrm{PC} 1$ and PC2. Principal component analysis (PCA) was made in R (ver.R-3.6.1) using R Package FactoMineR version 1.34 (Le et al. 2008).

Total contribution of each variable on explaining the variations retained by the two principal components was calculated by using $\mathrm{R}$ package factoextra version 1.0.5 (Kassambara et al. 2017). Among the correlated variables with a Kurtosis values $<2$, the variable showing the higher contribution of variation was retained; (4) to have good field sampling efficiency: following the example of Sabatini et al. (2015), each attribute was classified in three sampling efficiency classes, 1 (low), 2 (medium) and 3 (high). Attributes with higher values were preferred. Kurtosis values were calculated in Microsoft Excel 2013, while the rest analyses were carried out in R environment Version 3.5.2 (R Core Team 2018). 
A score ranging from 0 to 10 was assigned to each one of the eight retained variables. We first set a score of 2.5, 5, 7.5 and 10 to the quartile midpoints (corresponding to the 12.5, $37.5,62.5$ and 87.5 percentiles, respectively) of the raw attribute distribution. Then, a linear regression through quartile values was fitted to ensure that the attribute scores were evenly distributed between 0 and 10. This regression equation was used to associate a score with each observation (Table 2). Finally, a Structural Heterogeneity Index (SHI) was obtained by summing the scores in the range $0-10$ assigned to each variable in the core set, and then expressed as a percentage.

To evaluate the descriptive capacity of the SHI, it has been related to variables that are likely to be related with forest age and structural complexity, such as presence of cerambycids (higher presence associated with mature forest), canopy cover (higher canopy cover in older forests), forest layers (higher complexity of layers in mature forests), grazing (lower structural heterogeneity in forest with regeneration strongly affected by grazing) and location (easy coastal access favours the economic exploitation of the wood and the drier climate slows down its growth). Moreover, each site was classified according to the three old-growthness classes proposed for different types of Sicilian forests (Badalamenti et al. 2018). Such classification was based on field measurements of four internationally recognised indicators of oldgrowthness: deadwood, tree size, structural characteristics and tree species richness. In particular, for the proxy indicator "deadwood" was assigned a score ranging from 0 to 2 based on the total volume of dead tree values (DW) and the number of decay classes (DC): 0 for $\mathrm{DW} \leq 0.09,1$ for $0.09<\mathrm{DW} \leq 0.5$, and 2 for $\mathrm{DW}>0.5$, attributing one class higher if $\mathrm{DC} \geq 4$. For "structural characteristics", was assigned a suitability (1/0) based on the type of coverage (single, double or multi), on the value of the standard deviation and on the range of diameters. Also, for "tree size" and for the "tree species richness" was assigned only the suitability (1/0), based on the presence of trees with $\mathrm{DBH}>40 \mathrm{~cm}$ and on the number of species detected, respectively. On the basis of these 0-5 scores, each site was classified into three classes of old-growthness, as high ( $\mathrm{H}$, with scores $\geq 4$ ) medium ( $\mathrm{M}$, with scores $=3$ ) and low (L, with scores $<3)$. Differences among all the above-described characteristic parameters were graphically represented by box plots and tested using Kruskal-Wallis rank sum tests for pairwise comparisons and Dunn's test for multiple comparisons.

Table 2 Regression equations used to assign a score to attributes on a scale of $0-10$

\begin{tabular}{lcc}
\hline Structural indicator & Regression equation & $\mathrm{R}^{2}$ \\
\hline Hsd: Height standard deviation & $\mathrm{y}=1.010 \mathrm{x}+1.720$ & $\mathrm{R}^{2}=0.838$ \\
TreeRich: Tree species richness & $\mathrm{y}=1.446 \mathrm{x}+1.821$ & $\mathrm{R}^{2}=0.939$ \\
DensNLiv: Stem density, LOG+1 & $\mathrm{y}=7.789 \mathrm{x}-15.23$ & $\mathrm{R}^{2}=0.937$ \\
T>40: Number of living trees with DBH $>40 \mathrm{~cm}$ & $\mathrm{y}=0.535 \mathrm{x}+0.892$ & $\mathrm{R}^{2}=0.900$ \\
BA: Basal area, LOG & $\mathrm{y}=9.368 \mathrm{x}-12.30$ & $\mathrm{R}^{2}=0.896$ \\
Dw/liv: Deadwood/living wood volume ratio, RAD & $\mathrm{y}=9.281 \mathrm{x}+2.316$ & $\mathrm{R}^{2}=0.886$ \\
LenghtCWD: sum of lengths of every coarse woody debris piece, LOG+1 & $\mathrm{y}=4.436 \mathrm{x}+2.014$ & $\mathrm{R}^{2}=0.930$ \\
DensStuDW: Density of standing deadwood, LOG+1 & $\mathrm{y}=2.790 \mathrm{x}+2.106$ & $\mathrm{R}^{2}=0.945$ \\
\hline
\end{tabular}




\section{Results}

After field surveys, eight areas reported by questionnaires were excluded, as they showed clear signs of forest management. Accordingly, a total of 68 plots included in about 45 forest stands were selected for this study. Most of these plots $(67.7 \%)$ were in central-northern Sardinia (Fig. 1), while five plots each were sampled in the South-East and South-West side of Sardinia.

Two different forest types were mostly represented in this study: pure or mixed forests with Quercus ilex (42) and pure or mixed forests with Taxus baccata (15). Eleven plots where representative of persistent formations dominated by Juniperus sp.pl. ( $\mathrm{n}=5)$, Phillyrea latifolia L. and Arbutus unedo L. (n=2, each), and Quercus congesta and Alnus glutinosa $(\mathrm{n}=1$, each).

Eight structural indicators were identified (Table 3). The basal area (BA) and the density of standing deadwood (DensStuDW) were the most contributing variables. The reliability of these variables was confirmed by their high sampling efficiency.

Table 3 List of categories of structural complexity and the corresponding identified structural indicators with selection criteria

\begin{tabular}{|c|c|c|c|c|c|}
\hline Structural indicator & $\begin{array}{l}\text { Sources of structural } \\
\text { complexity }\end{array}$ & $\begin{array}{l}\text { Function as a } \\
\text { surrogate } \\
\text { (significant } \rho \leq 0.5 \text { ) }\end{array}$ & $\begin{array}{l}\text { Contribution of } \\
\text { variations by first } \\
\text { two principal } \\
\text { components }\end{array}$ & $\begin{array}{l}\text { Value of } \\
\text { Kurtosis }\end{array}$ & $\begin{array}{l}\text { Sampling } \\
\text { efficiency }\end{array}$ \\
\hline $\begin{array}{l}\text { Hsd: Height standard } \\
\text { deviation }\end{array}$ & $\begin{array}{l}\text { Vertical } \\
\text { heterogeneity }(\mathrm{VH})\end{array}$ & HM (0.689) & 1.670 & 1.807 & 2 \\
\hline $\begin{array}{l}\text { Treerich: Tree species } \\
\text { richness }\end{array}$ & $\begin{array}{l}\text { Compositional } \\
\text { diversity }(\mathrm{CH})\end{array}$ & - & 0.782 & -0.615 & 3 \\
\hline $\begin{array}{l}\text { DensNLiv: Stem density, } \\
\text { LOG }+1\end{array}$ & $\begin{array}{l}\text { Uneven-agedness } \\
\text { (UA) }\end{array}$ & $\begin{array}{l}\text { NDBH }(0.632) ; \\
\text { NstuStDW }(0.510) ; \\
\text { DensStuStDw }(0.510)\end{array}$ & 4.561 & -0.037 & 3 \\
\hline $\begin{array}{l}\mathrm{T}>40 \text { : Number of living } \\
\text { trees with } \mathrm{DBH}>40 \mathrm{~cm}\end{array}$ & $\begin{array}{l}\text { Density of large } \\
\text { living trees (LLT) }\end{array}$ & NHt (0.522) & 3.563 & 0.283 & 3 \\
\hline BA: Basal area, LOG & Growing stock (GS) & $\begin{array}{l}\text { RDBH (0.698); } \\
\text { Liv (0.868). } \\
\text { StDw (0.529); }\end{array}$ & 6.483 & 1.287 & 3 \\
\hline \multicolumn{2}{|c|}{$\begin{array}{l}\text { Dw/liv: Deadwood/living Total deadwood } \\
\text { wood volume ratio, RAD volume (DW-TOT) }\end{array}$} & $\begin{array}{l}\text { StuStDw }(0.565) \\
\text { BasnagSt }(0.543) \\
\text { CWD }(0.661) \\
\text { Dwtot }(0.786)\end{array}$ & 4.338 & 0.607 & 1 \\
\hline $\begin{array}{l}\text { LenghtCWD: sum of } \\
\text { lengths of every coarse } \\
\text { woody debris piece, } \\
\text { LOG+1 }\end{array}$ & $\begin{array}{l}\text { Deadwood decay } \\
\text { classes (DW-DC) }\end{array}$ & $\begin{array}{l}\text { CWD (0.843); } \\
\text { NDC (0.633); } \\
\text { Dwtot }(0.719)\end{array}$ & 4.542 & 0.317 & 3 \\
\hline $\begin{array}{l}\text { DensStuDW: Density } \\
\text { of standing deadwood, } \\
\text { LOG+1 }\end{array}$ & $\begin{array}{l}\text { Standing deadwood, } \\
\text { dead trees and snags } \\
\text { (DW-ST) }\end{array}$ & $\begin{array}{l}\text { BasnagST }(0.781) ; \\
\text { STDw }(0.814) ; \\
\text { StuStDw }(0.814) ; \\
\text { Dwtot }(0.517) ; \\
\text { DensNLiv }(0.510) ; \\
\text { GSDBH }(0.531)\end{array}$ & 5.611 & -1.287 & 3 \\
\hline
\end{tabular}

Notes: Sampling efficiency: 1 - poor, 2 - medium, 3 - high. See Table 1 for abbreviations. 
The SHI showed a normal distribution (Appendix B, supplementary Fig. 1), ranging from $25.6 \%$ to $76.6 \%$ (median $=50.31$ ). Results showed that the plots with the highest SHI values are those located in mountainous areas. All specific values related to each site, with ADSXX codes and toponyms, are reported in Table 4. Three sites located within the Gennargentu massif of central Sardinia (ADS29, ADS31, ADS32) accounted for high SHIs $(65.5 \%, 67.4 \%, 67.60 \%$, respectively). Another massif where several sites with high SHI were recorded is the Limbara in northern Sardinia. Here, SHIs range from 58.3\% (ADS58) to $61.5 \%$ (ADS41). In the southeastern Sardinian mountains of Sarrabus, plots with high SHIs were found in the locality of Buddidorgia (ADS06, ADS08, ADS09), with values of $61.7 \%, 65.3 \%, 72.5 \%$, respectively. In general, the 20 plots with the highest SHI values were often characterised by a high number of large trees (mean=10.15), high density of live trees (mean=517.89) and standing deadwood (mean=78.15), and high tree species richness (mean $=3.10)$. Coastal plots in the south-west (ADS38, ADS39) and in the centre (ADS11, ADS12) had lower SHI values $(33.3 \%, 36.2 \%, 41.8 \%, 47.5 \%$ respectively) and were characterised by a low amount of large trees (mean=1.75), tree species richness (mean $=2.00)$ and coarse woody debris (mean=0.24 m).

No significant difference $(p>0.05)$ was found by relating forest type with SHI. On the other hand, SHI significantly increased with higher percentages of canopy cover and with the number of canopy layers. SHIs were higher in absence of livestock grazing and when large longhorn beetles were present. Inland stands showed significantly higher SHIs than coastal. A significant correspondence among oldgrowthness classes and SHIs was found (Fig. 2).
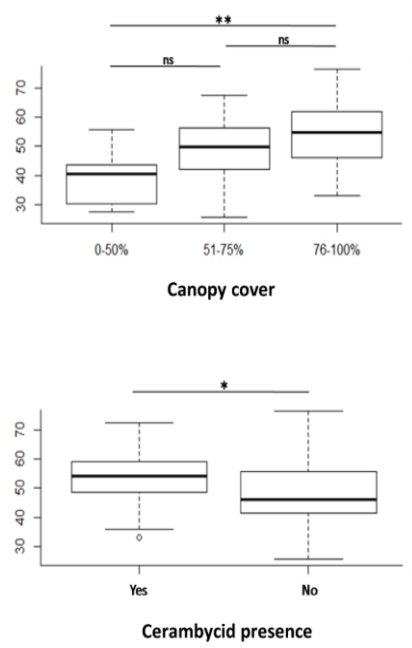
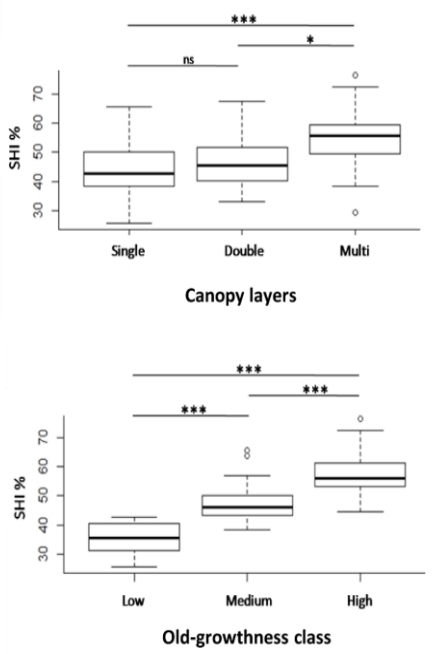

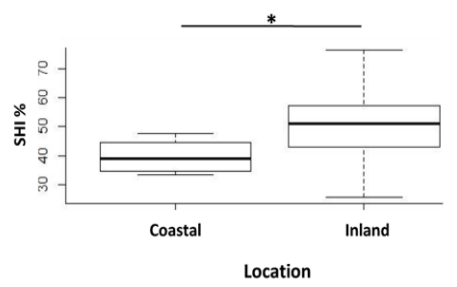

Figure 2 Boxplot of SHI across grazing, canopy cover, canopy layers (single, double, multi-layered), cerambycid presence, old-growthness class location plots. $\mathrm{Ns}=\mathrm{P}>0.05 ; *=\mathrm{P} \leq 0.05 ; * *=\mathrm{P} \leq$ $0.01 ; * * *=\mathrm{P} \leq 0.001$. Differences were tested using Kruskal-Wallis rank sum tests (pairwise) or Dunn's test (multiple comparisons; R-package "dunn.test"; Dinno 2016) using rank sums with Bonferroni correction 
Table 4 Specific values related to each site

\begin{tabular}{|c|c|c|c|c|c|c|c|c|c|c|c|c|c|c|}
\hline \multirow{3}{*}{ Name } & \multirow{3}{*}{$\begin{array}{l}\text { ID site } \\
\text { ADS_01 }\end{array}$} & \multirow[b]{2}{*}{ Loc. } & \multirow{3}{*}{\multicolumn{3}{|c|}{$\begin{array}{ccc}\text { Graz. Cer. } & \begin{array}{c}\text { Canopy } \\
\text { cover } \\
(\%)\end{array} \\
\text { No Yes } & 76-100\end{array}$}} & \multirow{3}{*}{$\frac{\mathrm{CL}}{\mathrm{D}}$} & \multirow{3}{*}{$\begin{array}{c}\mathrm{T}>40 \\
6\end{array}$} & \multirow{3}{*}{$\begin{array}{c}\text { Dens } \\
\text { StuDW } \\
37,66\end{array}$} & \multirow{3}{*}{$\begin{array}{c}\text { Dens } \\
\text { Liv } \\
583,80\end{array}$} & \multirow{2}{*}{\multicolumn{5}{|c|}{$\begin{array}{l}\text { N Tree CWD Old- } \\
\text { Liv Rich }(\mathrm{m}) \begin{array}{l}\text { growth SHI } \\
\text { class }\end{array}\end{array}$}} \\
\hline & & & & & & & & & & & & & & \\
\hline & & I & & & & & & & & 31 & 4 & 10.0 & $\mathrm{M}$ & 48.72 \\
\hline Aranzos & ADS_02 & I & Yes & No & $51-75$ & $\mathrm{~S}$ & 16 & 18,83 & 338,98 & 18 & 1 & 51.0 & M & 57.06 \\
\hline Baccu Addas_1 & ADS_03 & I & No & Yes & $51-75$ & M & 5 & 75,33 & 357,82 & 19 & 1 & 45.0 & $\mathrm{H}$ & 49.78 \\
\hline Baccu Addas_2 & ADS_04 & I & Yes & No & $51-75$ & M & 8 & 56,50 & 376,65 & 20 & 3 & 24.0 & $\mathrm{H}$ & 56.48 \\
\hline Bacu sa Figu & ADS_05 & I & No & Yes & $51-75$ & M & 3 & 131,83 & 395,48 & 21 & 4 & 25.0 & $\mathrm{H}$ & 56.11 \\
\hline Buddidorgia_1 & ADS_06 & I & No & No & $76-100$ & M & 11 & 0,00 & 508,47 & 27 & 4 & 75.5 & $\mathrm{H}$ & 61.67 \\
\hline Buddidorgia_2 & ADS_07 & I & No & No & $76-100$ & M & 11 & 0,00 & 451,98 & 24 & 2 & 8.0 & M & 46.24 \\
\hline Buddidorgia_3 & ADS_08 & I & No & Yes & $76-100$ & M & 13 & 131,83 & 602,64 & 32 & 5 & 20.0 & $\mathrm{H}$ & 65.30 \\
\hline Buddidorgia_4 & ADS_09 & I & No & Yes & $76-100$ & M & 13 & 207,16 & 696,80 & 37 & 5 & 117.0 & $\mathrm{H}$ & 72.49 \\
\hline Carracana & ADS_10 & I & No & Yes & $51-75$ & $\mathrm{~S}$ & 9 & 18,83 & 225,99 & 12 & 1 & 18.1 & M & 43.08 \\
\hline Cala Fuili & ADS_11 & $\mathrm{C}$ & No & No & $51-75$ & M & 2 & 56,50 & 659,13 & 35 & 2 & 8.0 & $\mathrm{~L}$ & 41.80 \\
\hline Puntali Mannu & ADS_12 & $\mathrm{C}$ & No & No & $51-75$ & M & 4 & 18,83 & 866,29 & 46 & 3 & 10.0 & $\mathrm{H}$ & 47.53 \\
\hline Dortesi & ADS_13 & I & Yes & Yes & $51-75$ & $\mathrm{~S}$ & 7 & 37,66 & 131,83 & 7 & 1 & 9.0 & M & 40.82 \\
\hline Goloritzè_1 & ADS_14 & I & Yes & No & $51-75$ & M & 5 & 0,00 & 131,83 & 7 & 3 & 12.0 & M & 38.37 \\
\hline Goloritzè_2 & ADS_15 & I & Yes & No & $51-75$ & $\mathrm{~S}$ & 3 & 0,00 & 56,50 & 3 & 1 & 4.0 & $\mathrm{~L}$ & 25.64 \\
\hline Gorroppeddu & ADS_16 & I & Yes & No & $51-75 \%$ & $\mathrm{~S}$ & 9 & 0,00 & 301,32 & 16 & 3 & 18.7 & $\mathrm{H}$ & 44.49 \\
\hline Is Arridelaxius & ADS_17 & I & No & No & $51-75$ & M & 8 & 18,83 & 376,65 & 20 & 3 & 34.0 & $\mathrm{H}$ & 49.02 \\
\hline Is Cannoneris & ADS_18 & I & No & No & $76-100$ & $\mathrm{~S}$ & 10 & 508,47 & 1996,23 & 106 & 2 & 25.0 & M & 63.79 \\
\hline Is Cioffus & ADS_19 & I & No & Yes & $51-75$ & M & 6 & 18,83 & 828,63 & 44 & 5 & 15.5 & $\mathrm{H}$ & 54.79 \\
\hline Janne 'e Cori & ADS_20 & I & Yes & Yes & $76-100$ & M & 10 & 225,99 & 470,81 & 25 & 1 & 11.2 & $\mathrm{H}$ & 54.25 \\
\hline La Signora & ADS_21 & I & Yes & Yes & & M & 7 & & & 35 & 2 & 59.6 & $\mathrm{H}$ & 59.66 \\
\hline Li Femmini & ADS_22 & I & No & Yes & $51-75$ & M & 4 & 56,50 & 753,30 & 40 & 2 & 15.1 & M & 48.64 \\
\hline Lispedda & ADS_23 & I & Yes & Yes & $51-75$ & M & 5 & 37,66 & 640,30 & 34 & 3 & 29.0 & $\mathrm{H}$ & 52.30 \\
\hline Canali mau_1 & ADS_24 & I & No & No & $76-100$ & M & 7 & 0,00 & 338,98 & 18 & 4 & 7.5 & M & 43.31 \\
\hline Canali mau_2 & ADS_25 & I & No & No & $76-100$ & M & 10 & 75,33 & 244,82 & 13 & 3 & 59.5 & $\mathrm{H}$ & 62.05 \\
\hline Mandra Brujata & ADS_26 & I & Yes & Yes & $51-75$ & $\mathrm{D}$ & 5 & 0,00 & 414,31 & 22 & 5 & 3.0 & $\mathrm{~L}$ & 40.38 \\
\hline Marmurata & ADS_27 & I & Yes & No & $51-75$ & $\mathrm{~S}$ & 4 & 0,00 & 320,15 & 17 & 3 & 14.5 & M & 42.33 \\
\hline Barbudu & ADS_28 & I & No & No & $51-75 \%$ & M & 5 & 18,83 & 414,31 & 22 & 2 & 53.0 & $\mathrm{H}$ & 53.66 \\
\hline Donnianigoro_1 & ADS_29 & I & Yes & Yes & $76-100$ & $\mathrm{~S}$ & 18 & 94,16 & 433,15 & 23 & 1 & 71.0 & M & 65.52 \\
\hline Fumai & ADS_30 & I & Yes & No & $51-75$ & $\mathrm{~S}$ & 9 & 18,83 & 188,32 & 10 & 1 & 4.8 & M & 43.25 \\
\hline Mereu & ADS_31 & I & Yes & Yes & $51-75$ & M & 15 & 75,33 & 583,80 & 31 & 2 & 100.0 & $\mathrm{H}$ & 67.41 \\
\hline Tureddu & ADS_32 & I & No & Yes & $51-75$ & $\mathrm{D}$ & 8 & 56,50 & 451,98 & 24 & 3 & 241.0 & $\mathrm{H}$ & 67.60 \\
\hline Monti di Deu_1 & ADS_33 & I & No & No & $76-100$ & $\mathrm{D}$ & 12 & 18,83 & 301,32 & 16 & 1 & 11.0 & M & 45.36 \\
\hline Monti di Deu_2 & ADS_34 & I & No & Yes & $51-75$ & M & 7 & & & 18 & 1 & 51.4 & M & 50.06 \\
\hline Mularza Noa & ADS_35 & I & No & No & $76-100$ & M & 11 & 94,16 & 659,13 & 35 & 6 & 60.0 & $\mathrm{H}$ & 76.59 \\
\hline Nieddoni & ADS_36 & I & Yes & Yes & $76-100$ & $\mathrm{~S}$ & 11 & 37,66 & 621,47 & 33 & 1 & 18.5 & M & 50.57 \\
\hline Oruddulè & ADS_37 & I & Yes & Yes & $51-75$ & $\mathrm{~S}$ & 9 & 18,83 & 244,82 & 13 & 4 & 31.0 & $\mathrm{H}$ & 54.59 \\
\hline Piscinas_1 & ADS_38 & $\mathrm{C}$ & Yes & No & $51-75$ & $\mathrm{~S}$ & 1 & 94,16 & 244,82 & 13 & 1 & 3.5 & $\mathrm{~L}$ & 33.32 \\
\hline Piscinas_2 & ADS_39 & $\mathrm{C}$ & Yes & No & $51-75$ & $\mathrm{~S}$ & 0 & 37,66 & 414,31 & 22 & 2 & 2.0 & $\mathrm{~L}$ & 36.25 \\
\hline Rio Aratu & ADS_40 & I & Yes & No & $51-75$ & $\mathrm{~S}$ & 4 & 94,16 & 207,16 & 11 & 2 & 2.0 & M & 49.63 \\
\hline Rio Columbano & ADS_41 & I & No & Yes & $51-75$ & M & 5 & 94,16 & 1167,61 & 62 & 3 & 49.2 & $\mathrm{H}$ & 61.46 \\
\hline Correboi_1 & ADS_42 & I & Yes & No & $0-50$ & M & 9 & 37,66 & 188,32 & 10 & 5 & 11.5 & $\mathrm{H}$ & 55.85 \\
\hline Correboi_2 & ADS_43 & I & Yes & No & $0-50$ & $\mathrm{~S}$ & 5 & 0,00 & 112,99 & 6 & 2 & 0.0 & $\mathrm{~L}$ & 31.28 \\
\hline Rodè & ADS_44 & I & No & Yes & $76-100$ & M & 7 & 37,66 & 564,97 & 30 & 4 & 10.2 & $\mathrm{H}$ & 55.62 \\
\hline Salbatore Logu & ADS_45 & I & No & No & $76-100$ & $\mathrm{D}$ & 5 & 56,50 & 772,13 & 41 & 4 & 17.0 & $\mathrm{H}$ & 53.12 \\
\hline Punta Salinas & ADS_46 & I & Yes & Yes & $51-75$ & M & 7 & 18,83 & 357,82 & 19 & 5 & 14.0 & $\mathrm{H}$ & 57.22 \\
\hline Sambuco Giuntura & ADS_47 & I & No & No & $76-100$ & M & 6 & 37,66 & 451,98 & 24 & 2 & 50.7 & $\mathrm{H}$ & 55.79 \\
\hline Sambuco Nord & ADS_48 & I & Yes & Yes & $0-50$ & $\mathrm{D}$ & 8 & 0,00 & 188,32 & 10 & 2 & 16.7 & M & 44.00 \\
\hline Trattalas_1 & ADS_49 & I & Yes & Yes & $0-50$ & M & 9 & 18,83 & 225,99 & 12 & 1 & 7.5 & M & 43.44 \\
\hline Trattalas_2 & ADS_50 & I & Yes & No & $0-50$ & $\mathrm{~S}$ & 10 & 0,00 & 188,32 & 10 & 1 & 11.0 & $\mathrm{~L}$ & 40.67 \\
\hline
\end{tabular}


Table 4 Specific values related to each site

\begin{tabular}{|c|c|c|c|c|c|c|c|c|c|c|c|c|c|c|}
\hline Trattalas_3 & ADS_51 & I & Yes & Yes & $51-75$ & $\mathrm{D}$ & 4 & 0,00 & 131,83 & 7 & 1 & 4.5 & $\mathrm{~L}$ & 35.89 \\
\hline Sos Nibberos & ADS_52 & I & Yes & No & $76-100$ & $\mathrm{~S}$ & 12 & 0,00 & 527,31 & 28 & 2 & 0.0 & $\mathrm{~L}$ & 42.74 \\
\hline Sos Nibberos_2 & ADS_53 & I & Yes & No & $76-100$ & $\mathrm{~S}$ & 14 & 56,50 & 451,98 & 24 & 2 & 10.0 & M & 55.97 \\
\hline Su Irove & ADS_54 & I & No & Yes & $51-75$ & M & 7 & 112,99 & 772,13 & 41 & 4 & 13.0 & $\mathrm{H}$ & 58.66 \\
\hline Su Prappare & ADS_55 & I & No & Yes & $76-100$ & M & 11 & 37,66 & 433,15 & 23 & 1 & 46.8 & $\mathrm{H}$ & 59.51 \\
\hline Su Suercone Ilex & ADS_56 & I & No & Yes & $51-75$ & $\mathrm{D}$ & 5 & 0,00 & 131,83 & 7 & 2 & 67.3 & $\mathrm{H}$ & 51.71 \\
\hline Su Suercone tassi & ADS_57 & I & No & No & $76-100$ & M & 10 & 301,32 & 414,31 & 22 & 1 & 63.9 & $\mathrm{H}$ & 63.46 \\
\hline Suliana & ADS_58 & I & No & Yes & $51-75$ & M & 8 & 94,16 & 583,80 & 31 & 3 & 25.2 & $\mathrm{H}$ & 58.26 \\
\hline Tedderieddu_1 & ADS_59 & I & Yes & No & $51-75$ & $\mathrm{M}$ & 6 & 18,83 & 131,83 & 7 & 4 & 10.8 & $\mathrm{H}$ & 51.19 \\
\hline Tedderieddu_2 & ADS_60 & I & Yes & No & $0-50$ & M & 6 & 0,00 & 131,83 & 7 & 1 & 0.0 & $\mathrm{~L}$ & 29.25 \\
\hline Tedderieddu_3 & ADS_61 & I & Yes & No & $76-100$ & $\mathrm{~S}$ & 9 & 0,00 & 169,49 & 9 & 2 & 4.0 & $\mathrm{~L}$ & 41.50 \\
\hline Tuones & ADS_62 & I & Yes & No & $0-50$ & $\mathrm{~S}$ & 3 & 0,00 & 94,16 & 5 & 2 & 0.0 & $\mathrm{~L}$ & 27.49 \\
\hline Tuviois_1 & ADS_63 & I & Yes & No & $51-75$ & $\mathrm{~S}$ & 5 & 18,83 & 112,99 & 6 & 1 & 14.2 & $\mathrm{~L}$ & 35.18 \\
\hline Tuviois_2 & ADS_64 & I & Yes & Yes & $76-100$ & $\mathrm{D}$ & 8 & 0,00 & 150,66 & 8 & 2 & 0.0 & $\mathrm{~L}$ & 33.03 \\
\hline Arcosu_Su Corteddu & ADS_65 & I & Yes & No & $76-100$ & $\mathrm{~S}$ & 5 & 0,00 & 451,98 & 24 & 1 & 8.0 & M & 41.78 \\
\hline Arcosu_Lattias & ADS_66 & I & No & No & $76-100$ & M & 5 & 56,50 & 1544,26 & 82 & 4 & 16.0 & $\mathrm{H}$ & 56.97 \\
\hline Arcosu_Longufresu_1 & ADS_67 & I & No & Yes & $76-100$ & M & 4 & 0,00 & 772,13 & 41 & 2 & 46.5 & $\mathrm{H}$ & 50.83 \\
\hline Arcosu_Longufresu_2 & ADS_68 & I & No & No & $76-100$ & $\mathrm{~S}$ & 11 & 0,00 & 414,31 & 22 & 3 & 12.0 & $\mathrm{M}$ & 46.68 \\
\hline
\end{tabular}

Notes: Name sites detected and ID (ADS XX), location (Loc.) of each site (coastal (C)/inland (I)), presence of grazing (Graz.) and cerambycids (Cer.); estimated \% of canopy cover; structure of canopy layers (CL): Multi (M), Double (D), Single (S); tree species richness; Old-growthness class estimated according to Badalamenti et al. (2018): High (H), Medium (M), Low (L). See Table 1 for the rest of abbreviations

\section{Discussion}

\section{Factors affecting forest heterogeneity in Sardinia}

Proxies related to growing stock and standing deadwood, namely BA and LenghtCWD, were themostcontributing variablesindiscriminating the examined plots. This confirmed again that the structural complexity of a forest stand is roughly equally defined by the co-presence of different characteristics related to both living and deadwood. For instance, plots with lower SHI values are characterised by a low number of large trees $(\mathrm{T}>40)$ and coarse woody debris (LenghtCWD). Under these conditions, the presence of few and majestic old trees, although they are quite important for the maintenance of saproxylic entomofauna, was unable to determine high structural heterogeneity. Low SHI values associated with low LenghtCWD are mainly explained by the removal and exploitation of dead wood by the local populations. In this sense, morphology and socio-economic factors are likely to be crucial drivers in inhibiting or favour the use of the land and consequently the permanence of old-growth forest stands. In particular, steep and mountainous morphologies have generally favoured the conservation of most of mature forest areas in the mountainous areas of Limbara and Gennargentu of central-northern Sardinia.

As regards the distribution of SHI values among plots, our results confirmed that the SHI is influenced by variables that are likely to be related with structural complexity, which was, in this case, measured by means of number of canopy layers. Although their management is debated, evidences that live-tree structural complexity is generally higher in old-growth than in mature and early transitional stands are ample. Among others, including also geomorphological aspects, big old trees have a crucial role in shaping a high structural complexity by determining a lower tree density and increased tree size heterogeneity (Zenner 2004). Moreover, coastal plots appear with lower SHI values than inland ones, probably as a consequence of higher 
human accessibility, economic interest and, possibly, to slower forest growth associated with dry climatic conditions and general low forest resilience of Mediterranean coastal areas (Mayor et al. 2007). As already reported for different European countries, livestock grazing (Bergmeier et al. 2010) and human activities (Motta 2002), appear to be crucial factors for shaping the structural variability of the forests in Sardinia and consequently old-growthness. Furthermore, our results showed significant differences of the SHI among the three levels of canopy cover, as well as among the number of canopy layers, confirming that such structural characteristics are discriminant characters for old-growthness definitions. Indeed, old growth forests have generally multiple or continuous canopy layers and are "bottom loaded" in foliage mass, in contrast to the top loaded canopies of young stands (Franklin \& Van Pelt 2004). The presence of large longhorn beetles was also weakly associated with higher structural complexity of forests, generally associated with mature trees and aging forests (Buse et al. 2008, Casula 2017).

\section{The SHI as a proxy forest of old-growthness and conservation value}

Although a large part of the Sardinian forests preserves traces of ancient human activities, such as paths and small plateaus for the coal production, and woodlands are currently still used for livestock grazing and firewood production, most of the investigated plots showed at least some characteristic or even a high level of old-growthness, which make them priority areas for conservation. In some cases, mature forests were maintained by the local communities who preserved them from cuts, recognising their cultural value, besides their productive function (Heatherington 2001) or, such as the plots with a high SHI value in "Buddidorgia" (ADS09, SHI up to 72.5\%), forest stands are interdicted under military jurisdiction since 1956.
However, signs of human impact, such as livestock grazing, were significantly influencing the SHI (i.e. a lower SHI in grazed stands). Even though grazing may in some cases favour forest development by, for instance, reducing litter and flammable biomass (Diaci et al. 2010), this is one of the main threats to the conservation of oldgrowth forests in Sardinia (Farris et al. 2012) and in other several Mediterranean areas (e.g., Bergmeier et al. 2010, Motta et al. 2015). The excessive trampling and/or herbivory of seedlings does not allow replacement of dead trees in the long term. An illustrative case is the secular Taxus baccata forest of "Sos Nibberos", where the presence of several large old trees is associated with the lack of renewal due to overgrazing. Moreover, the historical presence of human modifications was still visible in several investigated plots. For instance, small plateaus built by the charcoal burners are still visible, even if such practices were generally abandoned (Scotti \& Cadoni 2007). Following the definitions of Buchwald (2005), who developed an array of levels of naturalness of natural forests, we could classify part of the forests found in Sardinia as "relatively intact forest (stand level) that has been essentially unmodified by human activity for the past sixty to eighty years or for an unknown, but relatively long time", as in the case of high SHI values measured for ADS09 (SHI $72.5 \%$ ) or ADS32 (SHI 67.6\%). This was supported by the significant differences of SHIs among forest stands classified under three classes of old-growthness. Even though the SHI is not conceived for classifying oldgrowth forests, like the one proposed by Badalamenti et al. (2018), it can be used as a preliminary conservation priority-ranking measure of old- growth forests and persistent woodlands in Sardinia and other poorly investigated territories. Forests with high SHI stands should be prioritised for conservation and investigations aimed at understanding local processes underlying forest structural 
complexity and dynamics.

\section{Potential and limitations of the SHI}

One of the main advantages of the application of this methodology is that it comes from the sum of scores for each structural attribute, omitting the subjectivity due to a human evaluation. In this study, it was chosen to include in the SHI only those structural variables that can be easily measured in a plot of approx. $530 \mathrm{~m}^{2}$, which are proxies of other attributes very difficult and expensive to measure, such as biodiversity, the fraction of the gaps, or the interactions among biotic and/ or abiotic components. The structural attributes considered are a compromise between the relevance of information to include in the index and its cost, due to the large extent of the study area and the low available resources and information. Surprisingly, no significant differences were identified among the investigated forest and persistent woodlands types. On one side, this confirms that the $\mathrm{SHI}$ is unusable for comparisons among forest types. On the other side, the rarity of some forests such as the ones dominated by Phillyrea latifolia and Arbutus unedo, which does not allow achieving statistical significance in comparisons, suggests more specific and deeper studies on the structure dynamics of such uncommon typologies.

Although the SHI does not discriminate the process (anthropogenic or natural) that has determined the accumulation of a certain structural heterogeneity in a stand, humanrelated processes, such as livestock grazing, were confirmed to lower SHI values. Moreover, the index showed that, in some cases, plots with a different structure might have similar SHI values. An example can be the comparison of ADS18 (SHI 63.7\%), characterised by a high number of live trees and low values of tree species diversity, with ADS08 (SHI $65.3 \%$ ), characterised by a smaller number of live trees, but a high diversity of tree species.
Despite these differences, both plots showed roughly the same SHI value (Table 4). This suggests that old-growthness and maturity does not necessarily take into account the arboreal layer diversity, in accordance with McElhinny et al. (2005), which stated that structural complexity is a relative concept rather than absolute. Similarly, remarkable SHI values can be obtained in forest areas modified by silvicultural practices such as coppice with standards and retention forestry (Fedrowitz et al. 2014). An example is ADS45 (SHI 53.1\%), a typically biplane forest where a limited number of tall and large Quercus ilex trees dominate the lower layer of Phillyrea coppice.

\section{Conclusion}

The structural heterogeneity, in terms of SHI, of a representative sample of natural forests in Sardinia was for the first time elaborated. Specifically, a total of 68 plots included in 45 forest stands were here studied. Pure or mixed forests with Quercus ilex and pure or mixed forests with Taxus baccata were the most represented types. Similarly to other studies (e.g., Storch et al. 2018), the SHI was applied for analyses at a relative large spatial scale and for different types of forests, in an attempt to obtain an adequate assessment of the structural diversity of several forest types that co-occur in Sardinia. The SHI was mostly defined by the co-presence of both living and deadwood characteristics, namely basal area and density of standing deadwood, respectively. SHI increased with the number of canopy layers and canopy cover and it was likely to be disfavoured by overgrazing and by the soil-climatic and human accessibility conditions of coastal areas. Although a large part of the Sardinian forests preserves traces of ancient human activities, such as paths and small plateaus for the coal production, and woodlands are currently still used for livestock grazing and firewood production, most of the investigated plots showed at least 
some characteristic or even a high level of oldgrowthness, which make them priority areas for conservation.

This work produced a first characterisation of the ancient residual forests of Sardinia, which could be followed by more in-depth studies. On a small spatial scale, it would be interesting investigating which species respond as a maturity qualitative indicator. Among them, the presence of specific nemoral herbs/geophytes, such as Viola sp.pl., Glechoma sardoa (Bég.) Bég. or several ferns like Polystichum setiferum (Forssk.) Woyn. and Dryopteris oreades Fomin (Bacchetta et al. 2004a,b, Farris et al. 2012), moss-lichen assemblages with, for instance, Lobaria pulmonaria (Brunialti et al. 2010), fungi such as Fomes fomentarius (L.) Fr. (Bernicchia et al. 2008) and bats like Myotis mystacinus (Kuhl) and Plecotus sardus Mucedda, Kiefer, Pidincedda and Vieth (Mucedda et al. 2002, Kan̆uch et al. 2008) are just few of the rich array of species that might be investigated in this sense. On a large scale, the use of remote sensing techniques as the object oriented classification (Johansen et al. 2007), might allow an automated mapping and monitoring of their evolution through the identification of spatial structures typical of old growth forests, such as gaps or dead branches in the forest canopy. Furthermore, finding out which and how environmental and anthropogenic factors affect SHI might provide useful insights for forest conservation and management.

Even if it represents just a first step toward oldgrowth forests identification, considering the very sparse knowledge in the Mediterranean Basin, we believe that this method can be replicated in order to preliminarily assess the distribution and structure of old-growth forests and persistent woodlands at Mediterranean scale.

\section{Acknowledgements}

Many thanks to all the staff of the Forestry Agency of Sardinia and to the military staff of the Polygon of Inter-Service Test and Training Range of Salto di Quirra for their kind collaboration; without them, knowledge and access to many forest stands would have been impossible. The authors would like to acknowledge Sabina Burrascano for useful comments on an earlier version of this paper and to Rodrigo Pardo (University of CastillaLa Mancha) for his help in the sampling phase during his internship.

\section{References}

Abadie J., Avon C., Dupouey J. L., Lopez J. M., Tatoni T., Bergès L., 2018. Land use legacies on forest understory vegetation and soils in the Mediterranean region: Should we use historical maps or in situ land use remnants? For. Ecol. Manag. 427: 17-25. DOI: 10.1016/j.foreco.2018.05.050

Amici V., Santi E., Filibeck G., Diekmann M., Geri F., Landi S., Scoppola A., Chiarucci A., 2013. Influence of secondary forest succession on plant diversity patterns in a Mediterranean landscape. J. Biogeogr. 40: 23352347. DOI: $10.1111 /$ jbi.12182

Arar A., Nouidjem Y., Bounar R., Tabet S., Kouba Y., 2020. Modeling of the current and future potential distribution of Atlas cedar (Cedrus atlantica) forests revealed shifts in the latitudinal, longitudinal and altitudinal range towards more humid conditions. Ecol. Quest. 31: 1-22. DOI: $10.12775 / 29839$

Bacchetta G., Bagella S., Biondi E., Farris E., Filigheddu R.S., Mossa L., 2009. Vegetazione forestale e serie di vegetazione della Sardegna (con rappresentazione cartografica alla scala 1: 350.000) [Forest vegetation and vegetation series of Sardinia (at the resolution of 1: 350,000$]$. Società Italiana di Fitosociologia 46: 1-82.

Bacchetta G., Bagella S., Biondi E., Filigheddu R., Farris E., Mossa L., 2004a. A contribution to the knowledge of the order Quercetalia ilicis Br.-B1. ex Molinier 1934 of Sardinia. Fitosociologia 41: 29-51.

Bacchetta G., Biondi E., Filigheddu R., Farris E., Mossa L., 2004b. A phytosociological study of the deciduous oak woods of Sardinia (Italy). Fitosociologia 41: 53-65.

Badalamenti E., Pasta S., La Mantia T., La Mela Veca D.S., 2018. Criteria to identify old-growth forests in the Mediterranean: A case study from Sicily based on literature review and some management proposals. Feddes Repertorium 129: 25-37. DOI: 10.1002/ fedr.201700009

Bergmeier E., Petermann J., Schröder E., 2010. Geobotanical survey of wood-pasture habitats in Europe: diversity, threats and conservation. Biodivers. Conserv. 19: 2995-3014. DOI: 10.1007/s10531-0109872-3

Bernicchia A., Benni A., Venturella G., Gargano M.L., 
Saitta A., Gorjón S.P. 2008. Aphyllophoraceous woodinhabiting fungi on Quercus spp. in Italy. Mycotaxon 104: 425-428.

Biondi M., Urbani F., D’Alessandro P., 2013. Endemism patterns in the Italian leaf beetle fauna (Coleoptera, Chrysomelidae). ZooKeys 332: 177. DOI: 10.3897/ zookeys.332.5339

Blasi C., Marchetti M., Chiavetta U., Aleffi M., Audisio P., Azzella M.M., Brunialti G., Capotorti G., Del Vico E., Lattanzi E., Persiani A.M., Ravera S., Tilia A., Burrascano S., 2010. Multi-taxon and forest structure sampling for identification of indicators and monitoring of old-growth forest. Plant Biosyst. 144: 160-170. DOI: 10.1080/11263500903560538

Błonska E., Lasota J., da Silva G.R.V., Vanguelova E., Ashwood F., Tibbett M., Watts K., Lukac, M., 2020. Soil organic matter stabilization and carbon-cycling enzyme activity are affected by land management. Ann. For. Res. 63: 71-86. DOI: 10.15287/afr.2019.1837

Brunialti G., Frati L., Aleffi M., Marignani M., Rosati L., Burrascano S., Ravera, S., 2010. Lichens and bryophytes as indicators of old growth features in Mediterranean forests. Plant Biosyst. 144: 221-233. DOI: $10.1080 / 11263500903560959$

Buchwald E., 2005. A hierarchical terminology for more or less natural forests in relation to sustainable management and biodiversity conservation. In Proceedings: Third expert meeting on harmonizing forest-related definitions for use by various stakeholders. Proceedings. Food and Agriculture Organization of the United Nations, Rome (pp. 17-19).

Burrascano S., Rosati L., Blasi C., 2009. Plant species diversity in Mediterranean old-growth forests: a case study from central Italy. Plant Biosyst. 143: 190-200. DOI: $10.1080 / 11263500802709699$

Burrascano S., 2010. On the terms used to refer to 'natural' forests: a response to Veen et al. Biodivers. Conserv. 19: 3301-3305. DOI: 10.1007/s10531-010-9885-y

Burrascano S., Ripullone F., Bernardo L., Borghetti M., Carli E., Colangelo M., Pelle L, Rivelli A. R., Sabatini F. M., Schettino A., Siclari A., Uzunov D., Blasi C., 2018. It's a long way to the top: Plant species diversity in the transition from managed to old-growth forests. J. Veg. Sci. 29: 98-109.

Buse J., Ranius T., Assmann T., 2008. An endangered longhorn beetle associated with old oaks and its possible role as an ecosystem engineer. Conserv. Biol. 22: 329-337. DOI: 10.1111/j.1523-1739.2007.00880.x

Campetella G., Canullo R., Gimona A., Garadnai J., Chiarucci A., Giorgini D., Angelini E., Cervellini M., Chelli S., Bartha S., 2016. Scale-dependent effects of coppicing on the species pool of late successional beech forests in the central Apennines, Italy. Appl. Veg. Sci. 19: 474-485. DOI: 10.1111/avsc. 12235

Cardil A., Salis M., Spano D., Delogu G., Molina Terren D., 2014. Large wildland fires and extreme temperatures in Sardinia (Italy). iForest 7: 162. DOI: 10.3832/ifor1090-007
Casula P., 2017. Monitoring and management of Cerambyx cerdo in the Mediterranean region-a review and the potential role of citizen science. Nat. Conservation 19: 97. DOI: $10.3897 /$ natureconservation. 19.12637

Caterini F., 2013. Colpi di scure e sensi di colpa: storia del disboscamento della Sardegna dalle origini a oggi [Hits of axes and feelings of guilt: history of deforestation of Sardinia from its origins to today]. Delfino Editore, Sassari.

Chiavetta L., Sallustio V., Garfi M., Maesano M., Marchetti M., 2012. Classification of the oldgrowthness of forest inventory plots with dissimilarity metrics in Italian National Parks. Eur. J. For. Res. 131: 1473-1483. DOI: 10.1007/s10342-012-0622-9.

Chirici, G., Nocentini, S.,2013. Old-growth forests in Italy: recent research developments and future perspectives. Ital. J. For. Mt. Environ. 65: 475-480. DOI: 10.4129/ ifm.2010.5.01

Diaci J., Rozenbergar D., Boncina A. 2010. Stand dynamics of Dinaric old-growth forest in Slovenia: Are indirect human influences relevant? Plant Biosyst. 144: 194-201. DOI: 10.1080/11263500903560785

FAO-Forest Resource Assessment (FRA), 2015 Terms and Definitions, 2012. Forest Resources Assessment Working Paper 180. Rome: Food and Agriculture Organization of the United Nations http://www.fao. org/3/ap862e/ap862e00.pdf

Farris, E., Fenu, G., Bacchetta, G., 2012. Mediterranean Taxus baccata woodlands in Sardinia: a characterization of the EU priority habitat 9580. Phytocoenologia, 41: 231-246. DOI: 10.1127/0340-269X/2011/0041-0501

Fedrowitz K., Koricheva J., Baker S.C., Lindenmayer D.B., Palik B., Rosenvald R., Beese W., Franklin F., Kaouki J., Macdonald E., Messier C., SverdupThygeson A., Gustafsson L., 2014. Can retention forestry help conserve biodiversity? A meta-analysis. J. Appl. Ecol. 51: 1669-1679. DOI:10.1111/13652664.12289

Fenu G., Fois M., Cañadas E.M., Bacchetta G., 2014. Using endemic-plant distribution, geology and geomorphology in biogeography: the case of Sardinia (Mediterranean Basin). Syst. Biodivers.12: 181-193. DOI: 10.1080/14772000.2014.894592

Fois M., Fenu G., Bacchetta G., 2018. Identifying and assessing the efficiency of different networks of a finescale hierarchy of biodiversity hotspots. Plant Ecol. Divers. 11: 121-132. DOI:10.1080/17550874.2018.14 74281

Fois M., Fenu G., Bacchetta G., 2019. Estimating land market values from real estate offers: A replicable method in support of biodiversity conservation strategies. Ambio 48, 313-323. DOI: 10.1007/s13280018-1074-3

Fois M., Fenu G., Cañadas E. M., Bacchetta G., 2017. Disentangling the influence of environmental and anthropogenic factors on the distribution of endemic vascular plants in Sardinia. PloS one 12: e0182539. DOI: 10.1371/journal.pone.0182539 
Fortuny X., Carcaillet C., Chauchard S., 2020. Selective and taxon-dependent effects of semi-feral cattle grazing on tree regeneration in an old-growth Mediterranean mountain forest. For. Ecosyst. 7: 1-13. DOI: 10.1186/ s40663-020-00222-7

Franklin J. F., Van Pelt R., 2004. Spatial aspects of structural complexity in old-growth forests. J. Forestry. 102(3): 22-28. DOI: 10.1093/jof/102.3.22

Fridman J., Walheim M., 2000. Amount, structure, and dynamics of dead wood on managed forestland in Sweden. For. Ecol. Manag. 131: 23-36. DOI: 10.1016/ S0378-1127(99)00208-X

Gasparini P., Di Cosmo L., Floris A., Notarangelo G., Rizzo M., 2016. Guida per i rilievi in campo. INFC2015 - Terzo inventario forestale nazionale [Guidelines for field inventories - Third national inventory]. Consiglio per la ricerca in agricoltura e l'analisi dell'economia agraria, Unità di Ricerca per il Monitoraggio e la Pianificazione Forestale (CREA-MPF); Corpo Forestale dello Stato, Ministero per le Politiche Agricole, Alimentari e Forestali. 341 pp. https:// inventarioforestale.org (accessed 03 November 2019).

Gauquelin T., Bertaudiere V., Montes N., Badri W., Asmode J. F., 1999. Endangered stands of thuriferous juniper in the western Mediterranean basin. Biodivers. Conserv. 8: 1479-1498. DOI: 10.1023/A:1008966808796

Gauquelin T., Michon G., Joffre R., Duponnois R., Génin D., Fady B., Alifriqui M., Auclair L., Simenel R., Aderghal M., Baudoin E., Galiana A., Prin Y., Sanguin H., Fernandez C., Baldy V., 2018. Mediterranean forests, land use and climate change: a social-ecological perspective. Reg. Environ. Change 18: 623-636. DOI: 10.1007/s10113-016-0994-3

Gauthier S., Leduc A., Bergeron Y., 1996. Forest dynamics modelling under natural fire cycles: a tool to define natural mosaic diversity for forest management. Environ. Monit. Assess. 39: 417-434. DOI: 10.1007/ BF00396159

Grove A.T., Rackham, O., 2003. The nature of Mediterranean Europe: an ecological history. Yale University Press. London.

Heatherington T., 2001. Ecology, alterity and resistance in Sardinia. Soc. Anthropology 9: 289-306. DOI: 10.1111/ j.1469-8676.2001.tb00154.x

Hunter Jr M.L., 1990. Wildlife, forests, and forestry. Principles of managing forests for biological diversity. Prentice Hall. Englewood Cliffs, New Jersey USA

ISTAT, 2019. Istituto nazionale di statistica - Roma. https://www.istat.it/it

Janssen P., Fortin D., Hébert C., 2009. Beetle diversity in a matrix of old-growth boreal forest: influence of habitat heterogeneity at multiple scales. Ecography 32: 423-432. DOI: $10.1111 / \mathrm{j} .1600-0587.2008 .05671 . \mathrm{x}$

Jennings S.B., Brown N.D., Sheil D., 1999. Assessing forest canopies and understorey illumination: canopy closure, canopy cover and other measures. Forestry 72: 59-74. DOI: 10.1093/forestry/72.1.59

Johansen K., Coops N.C., Gergel S.E., Stange Y., 2007.
Application of high spatial resolution satellite imagery for riparian and forest ecosystem classification. Remote Sens. Environ. 110: 29-44. DOI: 10.1016/j. rse.2007.02.014

Kaňuch P., Danko Š., Celuch M., Krištín A., Pjenčák P., Matis Š., Šmídt J., 2008. Relating bat species presence to habitat features in natural forests of Slovakia (Central Europe). Mamm. Biol. 73: 147-155. DOI: 10.1016/j. mambio.2006.12.001

Kaplan J. O., Krumhardt K. M., Zimmermann N., 2009. The prehistoric and preindustrial deforestation of Europe. Quaternary Science Reviews 28: 3016-3034. DOI: 10.1016/j.quascirev.2009.09.028

Kassambara A., Mundt F., 2017. Package 'factoextra'. Extract and visualize the results of multivariate data analyses, 76. http:/www.sthda.com/english/rpkgs/ factoextra

Le S., Josse J., Husson F., 2008. FactoMineR: An R package for multivariate analysis. J. Stat. Softw. 25: 1-18. http://www.jstatsoft.org/v25/i01/

Lesica P., McCune B., Cooper S.V., Hong W.S., 1991. Differences in lichen and bryophyte communities between old-growth and managed second-growth forests in the Swan Valley, Montana. Can. J. Botany. 69: 1745-1755. DOI: 10.1139/b91-222

Lindenmayer D.B., Cunningham R.B., Donnelly C.F., Franklin J.F., 2000. Structural features of old-growth Australian montane ash forests. For. Ecol.Manag. 134: 189-204. DOI: 10.1016/S0378-1127(99)00257-1

Lombardi F., Chirici G., Marchetti M., Tognetti R., Lasserre B., Corona P., Barbati A., Ferrari B., Di Paolo S., Giuliarelli D., Mason F., Iovino F., Nicolaci A., Bianchi L., Maltoni A., Travaglini D., 2013. Deadwood in forest stands close to old-growthness under Mediterranean conditions in the Italian Peninsula. Ital. J. For. Mount. Environ. 65: 481-504. DOI: 10.4129/ ifm.2010.5.02

Lombardi F., Marchetti M., Corona P., Merlini P., Chirici G., Tognetti R., Burrascano S., Alivernini A., Puletti N., 2015. Quantifying the effect of sampling plot size on the estimation of structural indicators in old-growth forest stands. For. Ecol. Manag. 346: 89-97. DOI: 10.1016/j. foreco.2015.02.011

Marchetti M., Tognetti R., Lombardi F., Chiavetta U., Palumbo G., Sellitto M., Colombo C., Iovieno P., Alfani A., Baldantoni D., Barbati A., Ferrari B., Bonacquisti S., Capotorti G., Copiz R., Blasi C., 2010. Ecological portrayal of old-growth forests and persistent woodlands in the Cilento and Vallo di Diano National Park (southern Italy). Plant Biosyst. 144: 130-147. DOI: $10.1080 / 11263500903560470$

Mayor A.G., Bautista S., Llovet J., Bellot J., 2007. Post-fire hydrological and erosional responses of a Mediterranean landscape: Seven years of catchmentscale dynamics. Catena 71: 68-75. DOI: 10.1016/j. catena.2006.10.006

McElhinny C., Gibbons P., Brack C., 2006. An objective and quantitative methodology for constructing an index 
of stand structural complexity. For. Ecol. Manag. 235: 54-71. DOI: 10.1016/j.foreco.2006.07.024

McElhinny C., Gibbons P., Brack C., Bauhus J., 2005. Forest and woodland stand structural complexity: its definition and measurement. For. Ecol. Manag. 218: 1-24. DOI: 10.1016/j.foreco.2005.08.034

Motta R., 2002. Old-growth forests and silviculture in the Italian Alps: the case-study of the strict reserve of Paneveggio (TN). Plant Biosyst. 136: 223-231. DOI: 10.1080/11263500212331351129

Motta R., Garbarino M., Berretti R., Bjelanovic I., Borgogno Mondino E., Čurović M., Keren S., Meloni F., Nosenzo A., 2015. Structure, spatio-temporal dynamics and disturbance regime of the mixed beech-silver firNorway spruce old-growth forest of Biogradska Gora (Montenegro). Plant Biosyst. 149: 966-975. DOI: 10.1080/11263504.2014

Mucedda M., Kiefer A., Pidinchedda E., Veith M., 2002. A new species of long-eared bat (Chiroptera, Vespertilionidae) from Sardinia (Italy). Acta Chiropt. 4: 121-135. DOI: 10.3161/001.004.0202

Ódor P., Standovár T., 2001. Richness of bryophyte vegetation in near-natural and managed beech stands: the effects of management-induced differences in dead wood. Ecol. Bull. 49: 219-229. https://www.jstor.org/ stable/20113278

Ohlson M., Söderström L., Hörnberg G., Zackrisson O., Hermansson J., 1997. Habitat qualities versus longterm continuity as determinants of biodiversity in boreal old-growth swamp forests. Biol. Conserv. 81: 221-231. DOI: 10.1016/S0006-3207(97)00001-3

Paillet Y., Berges L., Hjalten J., Ódor P., Avon C., Bernhardt-Romermann M., Bijlsma R., De Bruyn L., Fuhr M., Grandin U., et al., 2010. Biodiversity differences between managed and unmanaged forests: Meta-analysis of species richness in Europe. Conserv. Biol. 24: 101-112. DOI: 10.1111/j.15231739.2009.01399.x

Parisi F., Lombardi F., Sciarretta A., Tognetti R., Campanaro A., Marchetti M., Trematerra P., 2016. Spatial patterns of saproxylic beetles in a relic silver fir forest (Central Italy), relationships with forest structure and biodiversity indicators. For. Ecol. Manag. 381: 217-234. DOI: 10.1016/j.foreco.2016.09.041

Parkes D., Newell G., Cheal D., 2003. Assessing the quality of native vegetation: the 'habitat hectares' approach. Ecol. Manag. Restor. 4: 29-38. DOI: 10.1046/j.1442-8903.4.s.4.x

Parviainen J., 2005. Virgin and natural forests in the temperate zone of Europe. For. Snow Landsc. Res. 79: 9-18.

Puddu G., Falcucci A., Maiorano L., 2012. Forest changes over a century in Sardinia: implications for conservation in a Mediterranean hotspot. Agroforest. Syst. 85: 319 330. DOI: 10.1007/s10457-011-9443-y

Pungetti G., 1995. Anthropological approach to agricultural landscape history in Sardinia. Landscape Urban Plan. 31: 47-56. DOI: 10.1016/0169-2046(94)01035-7

R Core Team, 2018. R: A language and environment for statistical computing. Version 3.6.1 R Core Team, R Foundation for Statistical Computing, Vienna, Austria. https://CRAN.R-project.org

Richard F., Moreau P.A., Selosse M.A., Gardes M., 2004. Diversity and fruiting patterns of ectomycorrhizal and saprobic fungi in an old-growth Mediterranean forest dominated by Quercus ilex L. Can. J. Bot. 82: 17111729. DOI: $10.1139 /$ b04-128

Rozas V., 2006. Structural heterogeneity and tree spatial patterns in an old-growth deciduous lowland forest in Cantabria, northern Spain. Plant Ecol. 185: 57-72. DOI: $10.1007 / \mathrm{s} 11258-005-9084-1$

Sabatini F. M., Burrascano S., Lombardi F., Chirici G., Blasi C., 2015. An index of structural complexity for Apennine beech forests. iForest 8: 314. DOI: 10.3832/ ifor1160-008

Sabatini F.M., Burrascano S., Keeton W.S., Levers C., Lindner M., Pötzschner F., Verkerk P.J., Bauhus J., Buchwald, E., Chaskovsky, O. ..., Kuemmerle T., 2018. Where are Europe's last primary forests? Divers. Distrib. 24: 1426-1439. DOI: 10.1111/ddi.12778

Scotti R., Cadoni M., 2007. A historical analysis of traditional common forest planning and management in Seneghe, Sardinia-lessons for sustainable development. For. Ecol. Manag. 249: 116-124. DOI: 10.1016/j. foreco.2007.05.027

Storch F., Dormann C.F., Bauhus J., 2018. Quantifying forest structural diversity based on large-scale inventory data: a new approach to support biodiversity monitoring. For. Ecosyst. 5: 34. DOI: 10.1186/s40663018-0151-1

Vicol I., 2016. Effect of old-growth forest attributes on lichen species abundances: A study performed within Ceahlău National Park (Romania). Cryptogamie, Mycologie 36: 399-407. DOI: 10.7872/crym/v36. iss4.2015.399

Zenner E.K., 2004. Does old-growth condition imply high live-tree structural complexity? For. Ecol. Manag. 195: 243-258. DOI: 10.1016/j.agrformet.2017.04.012

Ziaco E., Di Filippo A., Alessandrini A., Baliva M., D'Andrea E., Piovesan G., 2012. Old-growth attributes in a network of Apennines (Italy) beech forests: disentangling the role of past human interferences and biogeoclimate. Plant Biosyst. 146: 153-166. DOI: 10.1080/11263504.2011.650729 